\title{
THE STATE OF JUDICIAL SCRUTINY OF PUBliC CONTRACTING IN NEW ZEALAND AND CANADA
}

\author{
David Mullan*
}

\begin{abstract}
This article evaluates the varying ways in which the courts of New Zealand and Canada respond to arguments that government procurement exercises are subject to the principles and remedies of public law. While conceding that context is critical and that there are many, often competing considerations that are relevant in the evaluation of such arguments, the author contends that the courts in both countries should at least on occasion be open to the availability of public law remedies for misfired government procurement exercises, and, more importantly, whether by judicial review or civil action, to the deployment of public law principles in the assessment of the procedural and substantive components of government procurement. More generally, the author warns against the movement in both countries in the direction of the assimilation of public procurement within existing principles and remedies of private tendering law.
\end{abstract}

\section{PROLOGUE AND INTRODUCTION}

When I was an LLB student at Victoria University of Wellington in the mid to late 1960s, George Barton was my instructor in equity. When I was appointed as a junior lecturer, George had become Head of Department. In that capacity he took on roles as my mentor and, upon Ken Keith's going on leave to take up a United Nations appointment, surrogate LLM thesis supervisor. At a time when I was particularly in need of guidance as to my career path, George was readily available to both chat, and provide advice and information, but always in a way that recognised that personal preferences were important. In that context, he was very positive about my choice to pursue further graduate studies in Canada. Thereafter, George continued to be someone to whom I looked for

* Emeritus Professor of Law, Queen's University, Kingston, Ontario. In writing this paper in honour of George Barton, I was also very conscious of the shadow cast by a New Zealand giant in the field of the review of the contractual powers of government, the late Professor Michael Taggart. What I have produced is almost certainly only a pale imitation of what Mike would have had to say were he asked to reflect on recent developments in this controversial domain. 
encouragement and guidance. Throughout an academic career that kept me largely in Canada, I benefitted from George's critiques of my academic writing, and I was both instructed and stimulated by George's accounts of the work in which he was currently engaged. These accounts made me more aware than ever of the breadth of George's practice and, more significantly, his knowledge of and passion for the law and especially justice. His death came as a shock, and has left a void in my life in terms of a relationship that had evolved into a treasured friendship, but which had also continued to provide me with grounding in the pursuit of a career in law, even after I had retired from the academy.

When George taught equity, he seemed to me to be the quintessential private lawyer. It was only afterwards, when I took international law, that I learned that George's graduate work had been in public law and public international law in particular. ${ }^{1}$ During my time as a graduate student and junior lecturer, I benefitted greatly from his knowledge of public law and, in 1970, shortly before my departure for Canada, I went to see George in action in court as a public lawyer. The case was, of course, Parsons $v$ Burk, ${ }^{2}$ in which George, acting on behalf of the legendary Wellington bookseller Roy Parsons, attempted to enlist the aid of the ancient prerogative writ of ne exeat regno to prevent the All Blacks from departing the country for the 1970 tour of South Africa.

In that brave and imaginative challenge, George was unsuccessful, as he was to be some 11 years later in 1981 in Ashby $v$ Minister of Immigration. ${ }^{3}$ This case involved an action for a declaration that it would be an invalid exercise of power for the Minister of Immigration to grant temporary entry permits to the members of the Springbok rugby team about to embark on the most divisive sporting tour in New Zealand history. This time, George failed in both the Supreme (now High) Court and Court of Appeal. I do, however, like to think that it was George's advocacy in that case, coupled with the agonies of that tour, that ultimately laid the groundwork for the 1985 judgment of the Court of Appeal in Finnigan and Recordan $v$ New Zealand Rugby Football Union, ${ }^{4}$ a case in which George did not appear.

There, the Court of Appeal accorded standing to two members of local rugby clubs to challenge the decision of the Council of the New Zealand Rugby Football Union to accept yet another

1 His Cambridge doctoral thesis was on jurisdiction over visiting forces and, following his studies in England, he worked for two years in New York at the United Nations Human Rights Division.

2 Parsons v Burk [1971] NZLR 244 (SC Wellington).

3 Ashby v Minister of Immigration [1981] 1 NZLR 222 (CA).

$4 \quad$ Finnigan and Recordan v New Zealand Rugby Football Union [1985] 2 NZLR 159 (CA). 
invitation to send the All Blacks to South Africa that year. In delivering the judgment of the Court of Appeal, Cooke J (as he then was and one of the three judges in Ashby) famously declared: ${ }^{5}$

We are not holding that, not even discussing whether, the [Council's] decision is the exercise of a statutory power - although that was argued. We are saying simply that it falls into a special area where, in the New Zealand context, a sharp boundary between public and private law cannot realistically be drawn.

Here, some 14 years after Parsons $v$ Burk, the Court of Appeal gave recognition to what was at root the theory of the earlier cases: the proposition that, at least in New Zealand, the action of the sport of rugby's governing body could transcend the world of purely private law. Given the extent to which its decisions had a public impact, both within New Zealand and in terms of New Zealand's standing in the community of nations, it could be exposed to public law principles and possibly remedies. 6

Since then, issues involving the drawing of the line between private and public law have continued to arise in various other contexts, particularly as the role and forms of government have evolved, often dramatically. This paper in honour of George is about one such domain: the extent to which government contractual dealings (and in particular procurement) are subject to the principles and remedies of public law. For these purposes, my principal catchment area will be the case law of New Zealand and Canada. This is not, however, primarily a comparative study. Rather, my intention is that, by drawing upon the jurisprudence of these jurisdictions (as well as academic commentary), I will identify and discuss some of the issues of principle that are exposed by this case law. In short, my mission is to try to come to terms with what is involved in establishing a coherent set of operating rules in another domain where a sharp boundary between public and private law cannot be drawn.

\section{THE PROBLEM}

The problem is whether (and if so, to what extent) the law governing government contracting (and procurement in particular) is subject to principles and rules that do not affect contractual dealings among purely private parties. It is not a new one. Hammond J made this abundantly clear in his concurring judgment in the New Zealand Court of Appeal in Lab Tests Auckland Ltd v Auckland

5 At 179 .

6 For a fuller account and analysis, see Michael Taggart "The Impact of Apartheid on Commonwealth Administrative Law" in Hugh Corder (ed) Comparing Administrative Justice Across the Commonwealth (Juta, Cape Town, 2006) 158 at 168-172. 
District Health Board. ${ }^{7}$ There, with particular reference to judicial review of government contracts, he describes it as a "twilight" area of the law, ${ }^{8}$ one that had sprung into prominence over the past 25 years in the era of "Government by contract". ${ }^{9}$ He then states correctly that, "[u]nsurprisingly, courts have had the same sort of difficulty [as commentators] as to what approach the law should adopt". 10

Dr Graham Taylor in the second edition of Judicial Review: A New Zealand Perspective, agrees: "The problem has always been, and remains, how to deal with situations where legality impinges on commercial decisions". ${ }^{11}$

It is not, however, necessarily a problem for which there is a single answer. Hammond $\mathrm{J}$ identifies one way of conceiving of the challenge: ${ }^{12}$

Leaving to one side any applicable statutory provisions, the problem for the law, stated in the simplest terms, is whether to apply private law principles, public law principles, or some admixture of the two.

Implicit within this characterisation, however, are a range of critical sub-issues. In an era in which governments operate or attempt to advance their policies in an increasing variety of formats (including, crucially, partnerships with the private sector), ${ }^{13}$ how much depends on the nature of the entity entering into contracts and issuing Requests for Proposals (RFPs)? If one does not leave to one side applicable statutory provisions, what are the criteria on which courts should assess statutory regimes and provisions for the purposes of determining whether to insinuate public law values into the way in which such entities contract? Is there any room for the deployment of public law values when the matter comes before the court by way of an action for breach of contract (or even one in negligence, misrepresentation, misfeasance in public office, or restitution arising out of a contractual setting)? Does judicial review have any role to play in this domain? If so, under what configuration

7 Lab Tests Auckland Ltd v Auckland District Health Board [2008] NZCA 385, [2009] 1 NZLR 776, leave to appeal refused Diagnostic Medlab Ltd v Auckland District Health Board [2009] NZSC 10, (2009) 19 PRNZ 217.

8 At [351].

9 At [352].

10 At [356].

11 Graham Taylor (ed) Judicial Review: A New Zealand Perspective (2nd ed, LexisNexis, Wellington, 2010) at [2.23].

12 Lab Tests Auckland Ltd v Auckland District Health Board, above n 7, at [353].

13 Perhaps nowhere more so in terms of innovation and experimentation than in New Zealand. For an account of the origins of the New Zealand movement, see Michael Taggart "Corporatisation, Privatisation and Public Law" (1991) 2 PLR 77. 
of 'governmental' contracting powers? To what extent is access to judicial review limited by the statutory judicial review regime of a particular jurisdiction? If these and any other threshold barriers to judicial review are crossed, should courts apply the same principles of judicial review (both substantive and procedural) in this context that they do on other standard judicial review applications? Or does the judicial review of the exercise of 'governmental' contractual powers demand a special (and possibly narrower) range of judicial review grounds? To what extent, perhaps also as a threshold matter, should the courts, where judicial review of contractual activities might otherwise be available, look to the adequacy of remedies in contract, tort and restitution as a discretionary consideration in the granting of public law remedies?

I will commence by considering the current law in both New Zealand and Canada respecting the deployment of public law values in private law actions (and primarily breach of contract) in matters involving the range of what might be characterised as government contracting but with particular emphasis on procurement. I will then move to the law of judicial review applicable to such activities. There follows a critical evaluation of the current state of the law in which I attempt to provide some prescription as to the way in which the evolution of this area of the law should proceed.

\section{PRIVATE LAW ACTIONS INVOLVING 'GOVERNMENT' CONTRACTS}

\section{A Canada}

The 'two contract' theory now applicable in Commonwealth jurisdictions ${ }^{14}$ to contractual tendering was first developed by the Supreme Court of Canada in Ontario $v$ Ron Engineering \& Construction (Eastern) Ltd. ${ }^{15}$ Under this theory, the submission of a tender in general (though not invariably) gives rise to a contract (the so-called Contract A or process contract, to use New Zealand terminology). In return for consideration provided by the party soliciting tenders or issuing an RFP, the bidder is subject to an obligation to not withdraw the submitted bid, and if successful, to enter into the principal contract (Contract B). Estey J justified this rejection of the traditional theory in

14 For England and Wales see Blackpool \& Fylde Aero Club Ltd v Blackpool Borough Council [1990] 3 All ER 24 (CA); for Australia see Hughes Aircraft Systems International v Airservices Australia (1997) 146 ALR 1 (FC); and for New Zealand see Pratt Contractors Ltd v Palmerston North City Council [1995] 1 NZLR 469 (HC), and applied subsequently in Transit New Zealand v Pratt Contractors Ltd [2002] 2 NZLR 313 (CA), affirmed in Pratt Contractors Ltd v Transit New Zealand, [2003] UKPC 83, [2005] 2 NZLR 433 (PC).

15 Ontario v Ron Engineering \& Construction (Eastern) Ltd [1981] 1 SCR 111. 
that tenders were no more than a simple offer capable of acceptance at the opening of bids by the "owner" on the basis of the need to protect "the integrity of the bidding system". ${ }^{16}$

Most of the subsequent leading decisions in Commonwealth jurisdictions have also involved government procurement. However, there is nothing in Ron Engineering or any of those other leading decisions that in any way suggested that the two contract theory was restricted to government procurement. The terms of the various judgments did not in any sense locate the theory as one based on public law principles or the special considerations attending government procurement. Protecting the integrity of the bidding system was a principle founded in private law conceptions of the role of contract law and did not arise out of any more specific public policy principle than that.

What did, however, characterise most of the initial cases adopting and applying the two contract theory, including Ron Engineering itself, was that the protection that was being extended was to the owner or person soliciting bids, not the bidder. The principal aim was to force bidders once committed to a bid to remain in the process. Indeed, little consideration was given initially to the content of the consideration that passed from the owner or solicitor of bids to the bidder and that served to hold the bidder to the bid. That issue was only to arise once bidders started to sue when owners relied on extremely broad clauses in the call for tenders to not award contracts or reject specific bids. These clauses typically accorded owners the discretion to not accept any bids, to not necessarily accept the lowest bidder and, most dramatically, to accept bids that did not conform with the conditions of the call for proposals or tenders - the so-called 'privilege clauses'. If owners had such a broad discretion, did bidders in such cases really receive any consideration for their now binding promise not to withdraw a bid once it had been submitted?

In Canada, this issue first potentially surfaced in the Supreme Court of Canada in 1999 in MJB Enterprises Ltd v Defence Construction (1951) Ltd. ${ }^{17}$ It was finessed when the Court held that there was an implicit term to the effect that, at least in the absence of an explicit provision to the contrary, the owner would accept only compliant bids, an obligation that the owner had not met. A year later, however, in Martel Building Ltd v Canada, ${ }^{18}$ the Supreme Court did enunciate another implied term of the contract formed on the submission of a tender: an obligation on the part of the owner to treat all bids "fairly and equally."19

16 Ibid at 121.

17 MJB Enterprises Ltd v Defence Construction (1951) Ltd [1999] 1 SCR 619.

18 Martel Building Ltd v Canada [2000] 2 SCR 860.

19 At [88]. 
Even here though, and in the subsequent 2007 judgment in Double $N$ Earthmovers Ltd $v$ Edmonton (City), ${ }^{20}$ both cases involving public procurement, there was no suggestion that this duty to treat bidders "fairly and equally" was premised in any way on the nature of the owner and public law principles. In each instance, the recognition of the duty was based on the expectation of the bidders when they expended the time and money required to submit a bid. ${ }^{21}$ In other words, the duty was one that the Court conceived of as a component of the protection of the integrity of the bidding process. Indeed, in each instance, the Court made it clear that the content of the duty was one that had to be linked with the terms of the relevant call for tenders or RFP. Without going as far as dealing with the issue of whether this duty was one that could be excluded by an appropriately worded term, the Court saw the content of the duty to treat bidders fairly and equally as largely predicated on the way in which the owner had framed the call for tenders or RFP. In itself, this is quite at odds with any kind of transcendent public law principles applicable to government procurement. It is very much a situation specific private law conception of the rights and obligations of the parties.

That also emerges from the limited case law in which the courts have found a violation of the duty to treat bidders "fairly and equally". Bid-shopping after the closing of bids in reliance on a privilege clause can constitute a breach of that duty. However, it is once again clear from the judgment of the British Columbia Court of Appeal in the leading case of Stanco Projects Ltd $v$ British Columbia (Ministry of Water, Land and Air Protection), ${ }^{22}$ that the categorisation of bidshopping as an unfair practice is also predicated on preserving the integrity of the bidding process and applicable across both private sector and government tendering processes. Also, while the Supreme Court cited Stanco approvingly in Double $N,{ }^{23}$ it made it clear that subsequent negotiations of this kind were unobjectionable if specifically contemplated by the terms of the RFP. $^{24}$

Indeed, the extent to which the terms of the call for bids or RFP were controlling became abundantly clear in the Court's 2010 judgment in Tercon Contractors Ltd v British Columbia, ${ }^{25}$ another public sector procurement case. At issue here was liability for accepting a non-compliant

20 Double N Earthmovers Ltd v Edmonton (City) [2007] 1 SCR 116.

21 See Martel Building Ltd v Canada, above n 18, at [88] and Double N Earthmovers Ltd v Edmonton (City), above $n$ 20, at [32].

22 Stanco Projects Ltd v British Columbia (Ministry of Water, Land and Air Protection) 2006 BCCA 246,52 CLR (3d) 1, at [47]-[65].

23 Double N Earthmovers Ltd v Edmonton (City), above n 20, at [56].

24 Ibid at [58]-[60].

25 Tercon Contractors Ltd v British Columbia 2010 SCC 4, [2010] 1 SCR 69. 
bid in the face of an exclusion clause denying compensation to disappointed bidders "as a result of participating in this RFP". The entire Court accepted that an exemption clause could cover liability for accepting a non-compliant bid. It all depended on whether the clause, if interpreted properly, covered the breach in question, and, if it did, whether there was any basis for denying effectiveness to the application of the exemption clause by reference to the principles of unconscionability at the time of the contract's formation, or some conception of public policy sufficient to override the general public policy principle of freedom of contract.

For the majority, Cromwell $\mathrm{J}$ held that the clause properly interpreted did not cover the acceptance of a non-compliant bid. However, he expressly endorsed the minority's theory of the test that should be applied in the event that the clause did cover the breach complained of. ${ }^{26}$ In applying that approach, there is nothing in the minority judgment that would suggest in any way that the dissenting Judges were at all concerned about the fact this was a case involving public procurement. Here, as in the previous jurisprudence, the policy considerations at play were nothing other than those applied across the entire gamut of public and private sector contracting. Only Cromwell J (and then in the context of engaging in "interpretation" of the exemption clause) placed any reliance on the public nature of this tendering process. In the course of deploying, for the purposes of construing the exemption clause, the principle that the courts should strive to protect the integrity of the bidding process, Cromwell J continued: ${ }^{27}$

This factor is particularly weighty in the context of public procurement. In that context, in addition to the interests of the parties, there is the need for transparency for the public at large. This consideration is underlined by the statutory provisions which governed the tendering process in this case. That purpose is to assume transparency and fairness in public tenders.

However, that is a long way from any assertion that, even in the context of a private law action such as breach of contract, public procurement processes are amenable to the general procedural and substantive principles of public law. It is also clear that the majority has no truck with the argument that the public nature of this kind of procurement process should simply eliminate in all circumstances and notwithstanding the exclusion clause the acceptance of non-compliant bids.

26 At [62].

27 At [68]. Contrast the judgment of the New Zealand Court of Appeal in Transit New Zealand v Pratt Contractors Ltd, above n 14, at [77], where McGrath J, delivering the judgment of the Court of Appeal, made it clear that, in determining whether a tender process contract came into existence, no relevance was to be attached to the fact that the owner was a public body "[W]hether there is a binding promise as to process is to be ascertained by applying general principles of contract law concerning contract creation and implied terms". 
In her extensive case comment on Tercon Contractors, ${ }^{28}$ Jassmine Girgis noted that, as long ago as 1999 in a case comment on MJB Enterprises Ltd v Defence Construction (1951) Ltd, ${ }^{29}$ Stephen Waddams had advocated such an approach in the instance of public, as opposed to private tendering exercises. ${ }^{30}$ However, in a case that was ideally suited for a full consideration of whether the public nature of a procurement exercise constrained government issuers of calls for tender, the Court simply did not acknowledge it as an issue.

Of course, it might be argued that the Supreme Court of Canada should not be regarded as having determined this issue by default, and that the opportunity still exists in an appropriate case to argue for the application of principles of public law in the context of a government procurement exercise. However, given the extent to which the Supreme Court has consistently developed the law governing the conduct of RFPs in a way that both transcends public and private law boundaries and places enormous store in that context on the public policy of freedom of contract, it is impossible to be sanguine about the chances of success on such an argument at least in the short term.

Switching the focus to possible claims against public authorities in negligence arising out of contracting, including procurement, the Supreme Court of Canada has consistently maintained the position that administrative law "[i]nvalidity is not the test of fault and it should not be the test of liability". ${ }^{31}$ Rather, in Canada, issues of negligence liability in the contracting and procurement arenas are once again determined by reference to the jurisprudence governing such actions between private sector actors, subject however to limiting public law principles in the determination of whether there is a sufficient degree of proximity as to establish a duty of care between the parties to the process. In this context, in applying the second limb of the Anns $v$ London Merton London Borough Council test, ${ }^{32}$ and in determining whether there are residual policy considerations that preclude the imposition of a duty of care, the Canadian courts ${ }^{33}$ have excluded policy and quasijudicial functions from the ambit of the tort and taken into account other considerations bearing on

28 Jassmine Girgis "Tercon Contractors: The Effect of Exclusion Clauses on the Tendering Process" (2010) 49 CBLJ 187 at 209-211.

29 MJB Enterprises Ltd v Defence Construction (1951) Ltd, above n 17.

30 SM Waddams "Tenders for Construction Contracts" (1999) 32 CBLJ 308 at 310.

31 Welbridge Holdings Ltd v Winnipeg (Greater) [1971] SCR 957 at 969 per Laskin CJC, citing KC Davis Administrative Law Treatise (West Publishing Co, St Paul, Minnesota, 1958) vol 3 at 487.

32 Anns v Merton London Borough Council [1978] AC 728 (HL).

33 See for example Cooper v Hobart 2001 SCC 79, [2001] 3 SCR 537 at [38]. 
public bodies' role as contractors such as "the spectre of liability to an indeterminate number of people." 34

This invocation of public interest considerations does, of course, mean that there are distinct principles that may be relevant to the determination of public authority liability in negligence. However, what is obvious is that these principles bear no relationship to the normal common law grounds of judicial review but rather are liability limitation factors. In short, they do not beg the argument as to the relevance of judicial review principles in governmental liability cases. Indeed, more generally, the Supreme Court of Canada, in a statement of principle applicable to both private and public procurement processes, has minimised further the extent to which negligence liability will arise out of such functions. This was in Design Services Ltd $v$ Canada, ${ }^{35}$ a public procurement case in which a subcontractor of an unsuccessful bidder was attempting to sue the owner, the Government of Canada, in negligence. In addition to holding that there was no duty of care between the owner and subcontractors of the bidder by reference to both the first and second limbs of the Anns test, Rothstein J, delivering the judgment of a unanimous Court, continued: ${ }^{36}$

To conclude that an action in tort is appropriate when commercial parties have deliberately arranged their affairs in contract would be to allow for unjustifiable encroachment of tort law into the realm of contract.

In other words, contract will remain the primary, if not exclusive venue for the vindication of rights arising out of tendering process contracts. ${ }^{37}$ It is also highly unlikely in the wake of Alberta $v$ Elder Advocates of Alberta Society that there is any room for the recognition of a fiduciary duty arising out of the relationship between bidders and public authorities in tendering processes. ${ }^{38}$ There, the Supreme Court of Canada put paid to any evolution in the direction of imposing on public authorities, save in limited and very special circumstances, a general fiduciary duty towards those affected by the exercise of their powers.

Outside of contract, what then is left in the domain of civil liability? Presumably, there may be occasions where actions in restitution and misfeasance in public office are appropriate litigation responses to failings in the conduct of public procurement. ${ }^{39}$ In both those situations, the grounds of

34 Ibid at [37].

35 Design Services Ltd v Canada 2008 SCC 22, [2008] 1 SCR 737.

36 At [56].

37 Of course, not all calls for tenders and RFPs will give rise to a process contract as Cromwell J makes clear in Tercon Contractors, above n 25, at [17]. In those cases, there may be room for the deployment of tort.

38 Alberta v Elder Advocates of Alberta Society 2011 SCC 24, [2011] 2 SCR 261.

39 See for example Powder Mountain Resorts Ltd v British Columbia (2001) 94 BCLR (3d) 14 (CA). 
judicial review of administrative action (and illegality in particular) may very well provide a starting point for the making of such claims.

\section{B New Zealand}

As opposed to Canada, there is New Zealand case law addressing the issue of the invocation of the public law principles of judicial review in the context of a breach of contract action arising out of a public sector procurement exercise. In Transit New Zealand v Pratt Contractors Ltd, ${ }^{40}$ at first instance, ${ }^{41}$ Goddard $\mathrm{J}$ had expressed her finding of a breach of the tender process contract in terms of the common law, judicial review principles of bias. On the facts, Transit's tender evaluation team contained members of whom there was a reasonable apprehension of bias. In so far as this amounted to an insinuation of public law grounds of review and went beyond the contractual obligation to treat all bidders fairly and in good faith, McGrath $\mathrm{J}$ of the Court of Appeal rejected the position taken by the trial judge: ${ }^{42}$

There is also a danger in judicial scrutiny of judgments made in this area if the Court applies standards akin to those required in judicial review proceedings involving exercise of statutory powers. ... Goddard $\mathrm{J}$ in this case found against Transit because of her finding of apparent bias of members of the first evaluation team, which is of course on the basis of a judicial review concept. We do not consider there is a contractual obligation on Transit to avoid conducting its evaluation in a way which would leave a statutory officer open to judicial review for apparent bias.

On further appeal to the Judicial Committee of the Privy Council, ${ }^{43}$ Lord Hoffmann made reference to this aspect of the Court of Appeal's judgment, ${ }^{44}$ and, subsequently, ${ }^{45}$ appeared to endorse it by reference to the following statement by Finn $\mathrm{J}$ of the Federal Court of Australia in Hughes Aircraft Systems International v Airservices Australia, a statement also referenced by the New Zealand Court of Appeal. ${ }^{46}$ The implied term requiring a public authority issuing an RFP to act in good faith and fairly: ${ }^{47}$

\footnotetext{
40 Transit New Zealand v Pratt Contractors Ltd, above n 14.

41 Pratt Constructors v Transit New Zealand Ltd HC Wellington CP 221/97, 6 September 2000.

42 Transit New Zealand v Pratt Contractors Ltd, above n 14, at [98].

43 Pratt Contractors Ltd v Transit New Zealand, above n 14.

44 At [41]

45 At [46]-[47].

46 Transit New Zealand v Pratt Contractors Ltd, above n 14, at [98].

47 Pratt Contractors Ltd v Transit New Zealand, above n 14, at [42].
} 
... does not as such impose on [the employer] under the guise of contract law, the obligation to avoid making its decision or otherwise conducting itself in ways which would render it amenable to judicial review.

Nonetheless, Lord Hoffman did deal with the appeal using concepts with at the very least public law judicial review analogues. The implied obligations did not mean that Transit "had to act judicially". ${ }^{48}$ It did not involve Transit in affording the bidder "a hearing or enter[ing] into a debate with him about the rights and wrongs of" the bidder's conduct in relation to another procurement exercise. ${ }^{49}$ Nonetheless, earlier Lord Hoffmann had referred to the failure of the Court of Appeal to address whether the trial judge may in reality have "made findings of actual as well as apparent bias", a failure that it excused because of other considerations. ${ }^{50}$ Lord Hoffmann also went on to consider whether the conduct of the members of the evaluation team constituted bad faith such as by refusing to take into account information that might show that, on the facts, their views about the probity of the bidder were incorrect.

None of this discussion would have been out of place in a public law judicial review application, as apparent from the following characterisation: the nature of the governmental power being exercised did not require the imposition of a more judicialised process and it was not appropriate to adjudge the evaluators from the perspective of a reasonable apprehension of bias. ${ }^{51}$ Rather, the appropriate test in this context was actual bias. Further, while no formal hearing, or even involvement of Pratt, was necessary in relation to the contentious issue of Pratt's prior record in procurement exercises, it was nonetheless incumbent on members of the evaluation team not to ignore evidence that might contradict their preconceived views. To do so would amount to reviewable bad faith even in a context where there was no duty to act judicially.

This is not meant to assert that the Privy Council was deliberately leaving the matter unresolved. However, there is certainly enough wiggle room in the terms of its judgment to suggest that this was not the final word as far as New Zealand law is concerned about the deployment of public law

48 At [47].

49 Ibid.

50 At [42].

51 In a previous era, this approach might well have been justified in a Canadian judicial review context on the basis that those bidding on government contracts were mere applicants or benefit seekers not entitled to the protection of the rules of procedural fairness: Webb v Ontario Housing Corporation (1978) 93 DLR (3d) 187 (Ont CA). In delivering the judgment of the Court, MacKinnon ACJO stated (at [21]):

The determination to grant her this benefit was made when she was accepted as a tenant [of Ontario government subsidised housing]. That decision was one that, in my view, could be made by OHC without any intervention of a rule or principle of "procedural fairness." 
judicial review grounds, both procedural and substantive, in breach of tender process contract actions. I would similarly argue, despite my earlier misgivings, that the issue is not precluded definitively in Canadian law given the absence of any real discussion of the intersection in breach of tender process contracts between the duty to act fairly and treat all bidders equally and the standards and grounds of review in Canadian judicial review law.

\section{PUBLIC LAW JUDICIAL REVIEW OF 'GOVERNMENT' CONTRACTING}

\section{A Canada}

As early as 1990, a Canadian court accepted the argument that government procurement could be subject to judicial review. This was in Thomas C Assaly Corp $v$ Canada, where Strayer $\mathrm{J}$ set aside a procurement process on the ground of procedural unfairness. ${ }^{52}$ More specifically, the Department of Public Works had led the suing bidder to believe that it was qualified and that the contract would be awarded on the basis of price only. In fact, the contract was awarded to the highest bidder with the Department treating the suing bidder as disqualified. The Trial Division Judge of the Federal Court held that it was incumbent on the Department to provide the suing bidder with notice of its changed position and to afford the bidder an opportunity to address that matter. In reality, the principle of which review was granted was closely akin to that of legitimate expectation. In providing relief, Strayer J noted that the awarding of the contract was an administrative function provided for in subordinate legislation authorised by an Act of Parliament. He continued: ${ }^{53}$

There are not broad policy functions involving unlimited discretion. Decisions with respect to the acceptance or rejection of bids directly affect the interests of persons invited to bid who have undertaken the trouble and expense to tender and to hold their property available until a decision is made. There is therefore attached a duty of fairness that the courts can enforce by certiorari.

Two other aspects of this foundational precedent do, however, merit attention. Strayer J was careful to base his decision on procedural, not substantive grounds: "If this were exclusively a matter of unfairness of result I am not sure it would have been an appropriate case for judicial intervention". ${ }^{54}$

He also rejected the argument that an action for a breach of contract or the tort of misrepresentation was a more appropriate remedy. In so doing, he noted that such an action "would

52 Thomas C Assaly Corp v Canada (1990) 44 Admin LR 89 (FCTD).

53 At 92 .

54 Ibid. 
require a trial involving difficult issues of fact and law". ${ }^{55}$ At least in this context, judicial review in the form of a setting aside of the award of the contract served to provide the disappointed bidder with another opportunity to secure the contract, something that would have been difficult to accomplish through an action based on breach of contract or misrepresentation.

Five years later, in Gestion Complexe Cousineau (1989) Inc v Canada (Minister of Public Works and Government Services), ${ }^{56}$ the Federal Court of Appeal affirmed the reviewability under the then Federal Court Act 1985 of statutorily based tendering processes, in this instance a call for bids in relation to the leasing of property. ${ }^{57} \mathrm{~A}$ year earlier, the Northwest Territories Court of Appeal in Volker Stevin NWT (1992) Ltd v Northwest Territories (Commissioner), had also recognised the availability of judicial review of a decision taken on the basis of a process established by directive to remove the applicant for relief from the list of those eligible to bid on government contracts. ${ }^{58}$

However, it was certainly not the case that there was unanimity among Canadian courts as to the availability of public law remedies as a way of contesting government procurement decisions. Thus, for example, in 1991, the same year as Thomas C Assaly, in St Lawrence Cement Inc v Ontario (Minister of Transportation), Montgomery J of the Ontario Court (General Division) refused to countenance the availability of certiorari to quash a procurement decision. ${ }^{59}$ The Ministry's call for bids for the construction of a highway was "a commercial contract which in no way affects the public interest." 60 This was so notwithstanding the existence of a specific statutory provision in the Public Transportation and Highway Improvement Act 1980 authorising the Minister to enter into such contracts. ${ }^{61}$

In terms of the subsequent, though still limited, evolution of the jurisprudence relating to this issue, there are two developments in the general principles of Canadian judicial review law that must be recognised.

55 At $94-95$.

56 Gestion Complexe Cousineau (1989) Inc v Canada (Minister of Public Works and Government Services) [1995] 2 FC 694 (CA)

57 Federal Court Act RSC 1985 c F-7 (as amended by Crown Liability and Proceedings Act SC 1990 c 8).

58 Volker Stevin NWT (1992) Ltd v Northwest Territories (Commissioner) (1994) 113 DLR (4th) 639 (NWTCA).

59 St Lawrence Cement Inc v Ontario (Minister of Transportation) (1991) 3 OR (3d) 30 (OCGD).

60 Ibid at 38.

61 Public Transportation and Highway Improvement Act RSO 1980 c 421, s 26(1). 
First, in Knight v Indian Head School Division No 19, ${ }^{62}$ the Supreme Court of Canada extended the application of the principles of public law procedural fairness to the dismissal of a contractual employee of the School Division, an employee whose position was provided for in the relevant statute but whose position was technically held at pleasure. In so holding, L'Heureux-Dubé J (for the majority) had prefaced her analysis with the following statement of principle: ${ }^{63}$

It should be noted at this point that the duty to act fairly does not depend on doctrines of employment law, but stems from the fact that the employer is a public body whose powers are derived from statute, powers that must be exercised according to the rules of administrative law. It is in that context that the employee-employer relationship between the respondent and the appellant Board must be examined, with the result that the analysis must go beyond the contract of employment to encompass arguments of public policy.

Later, she continued: 64

As opposed to the employment cases dealing with "pure master and servant" relationships, where no delegated statutory powers are involved, the public has an interest in the proper use of administrative power by administrative bodies.

To the extent that these statements rely on principles associated more generally with the exercise of specific delegated statutory powers, they obviously have the potential to transcend the context of designated statutory positions held at pleasure. They also apply to government procurement in such a way as to create an entitlement to review at least in terms of contractual powers having a clear or specific statutory origin (as perhaps opposed to contracts merely incidental to the effective operation of a government department or other public body).

All of this changed, however, in 2008 in Dunsmuir v New Brunswick. ${ }^{65}$ There, in another public employment case, the Supreme Court specifically repudiated the aspects of Knight just described. ${ }^{66}$ It held that, with very few exceptions, ${ }^{67}$ where a public office holder's engagement is the subject of an employment contract, disputes relating to that contract including dismissal, should be governed by the terms of the contract (both express and implied), the common law of contract, and any relevant statutory provisions. There was no room for the engrafting of a public law duty of fairness,

62 Knight v Indian Head School Division No 19 [1990] 1 SCR 653.

63 At 22 .

64 At [32].

65 Dunsmuir v New Brunswick 2008 SCC 9, [2008] 1 SCR 190.

66 At [81]-[117].

67 At [115]. 
and the office holder was confined to contractual remedies. ${ }^{68}$ There were two principal reasons for this seismic shift. First, the Court did not accept as workable a distinction between appointments with a statutory flavour sufficient to attract the principles and remedies of public law and those ordinary government master and servant contracts lacking such a statutory grounding. Secondly, the Court also was of the view that the remedies for breach of contract were more appropriate across virtually the entire range of government appointments than those available through judicial review. Of these reasons, the second has obvious implications for government procurement exercises, the first less obviously so.

The second relevant development in general judicial review law can be traced to the judgment of L'Heureux-Dubé J in Baker v Canada (Minister of Citizenship and Immigration). ${ }^{69}$ This was a case involving an illegal overstayer. However, for present purposes, the facts are incidental. What is significant is that L'Heureux-Dubé J rejected any clear-cut distinction between law and discretion and held that, whatever the nature of the power in issue, courts conducting judicial review on substantive grounds were obliged to establish a standard of review before proceeding to a consideration of the merits of the challenge. Subsequently, in $\operatorname{Dr} Q v$ College of Physicians and Surgeons of British Columbia, ${ }^{70}$ McLachlin CJ, for an unanimous Court, described this as the recognition of, "an overarching or unifying theory for review of substantive decisions of all manner of statutory or prerogative authorities". ${ }^{71}$

What this meant was that in the wake of Dunsmuir, also the leading Canadian authority on standard of review, when substantive review is in play, the reviewing court must first conduct a standard of review analysis and determine whether the decision in issue is subject to correctness or reasonableness review, no matter how awkward the fit. In reinforcement of this, the Supreme Court has subsequently applied this approach to review of broad discretionary powers, including the promulgation of bylaws by municipalities. ${ }^{72}$

68 Subsequently, the Supreme Court of Canada did, however, make it clear that Dunsmuir did not go so far as to preclude recourse to public law remedies whenever a contract was in play. This was in Canada (Attorney General) v Mavi 2011 SCC 30, [2011] 2 SCR 504, at [47]-[51], where the Court recognised that a limited public law duty of procedural fairness applied to the exercise of government power to recover money from sponsors of family reunification immigrants to Canada, albeit that that was a power recognised in a contract between the Government and the sponsor. Specifically, at [50]: ... "while the sponsors' undertakings here have some contractual aspects, it is the statutory framework that closely governs the rights and obligations of the parties and opens the door to the requirements of procedural fairness".

69 Baker v Canada (Minister of Citizenship and Immigration) [1999] 2 SCR 817.

70 Dr Q v College of Physicians and Surgeons of British Columbia 2003 SCC 19, [2003] 1 SCR 226.

71 At [25], citing David J Mullan Administrative Law (Irwin Law, Toronto, 1999) at 108.

72 See for example Catalyst Paper Corp v North Cowichan (District) 2012 SCC 2, 340 DLR (4th) 385. 
At first blush, that might be seen as having clarified and opened up considerably the review possibilities for the substance of public procurement decisions, or at least those with a sufficiently statutory flavour. However, in fact, the spectre of even reasonableness review seems more likely to have driven lower courts in the direction of using various devices for simply forcing substantive review of procurement decisions off the public law agenda. Among the vehicles for achieving this abdication are the concept of justiciability, decreasing the range of what is truly public in the exercise of contractual power, confining (as foreshadowed by Dunsmuir) bidders on government contracts to the realm of the private law of contract, interpreting narrowly the reach of judicial review remedial statutes, and the strategic use of judicial discretion not to award public law remedies.

Two modern decisions, in particular, are not only illustrative of these tendencies but also indicative of the extent to which the law governing judicial review of procurement decisions in Canada is still in a state of turmoil or confusion.

In 2169205 Ontario Inc (cob Lefroy Freshmart) v Ontario (Liquor Control Board), ${ }^{73}$ the Ontario Divisional Court refused to entertain an application for judicial review of a procurement decision under the province's judicial review statute, the Judicial Review Procedure Act $1990 .{ }^{74}$ The procurement in question was an RFP for the operation in a small Ontario community of an agency liquor store. The Liquor Control Board had specific statutory authority to establish government liquor stores and decide where they would be located. However, Swinton J, delivering the judgment of a unanimous Court, did not see this as providing a sufficient basis for an application for judicial review relating to the choice of private sector operator acting as agent of the government in a small Ontario community. According to the Court, this did not amount to a "statutory power of decision", a statutory term that the Court appeared to treat as a threshold to the availability of review under the Judicial Review Procedure Act. Leaving aside the question of whether the Act applied only to the exercise of a "statutory power of decision", a proposition that was in fact contrary to the jurisprudence, ${ }^{75}$ the Court spoke more generally of the decision as one that was not sufficiently public in its nature as to be amenable to the grounds and remedies of judicial review: ${ }^{76}$

Courts have traditionally considered the process of awarding a government contract for goods and services to be a commercial matter that is governed by private law. In particular, it has been held that the decision to award a contract is not properly a subject for judicial review where there are no statutory

732169205 Ontario Inc (cob Lefroy Freshmart) v Ontario (Liquor Control Board) 2011 ONSC 1878 (Div Ct).

74 Judicial Review Procedure Act RSO 1990 c J1.

75 See Bezaire v Windsor Roman Catholic Separate School Board (1992) 9 OR (3d) 737 (Div Ct).

762169205 Ontario Inc (cob Lefroy Freshmart) v Ontario (Liquor Control Board), above n 73, at [24]. 
provisions or regulations which prescribe how the government agency is to go about entering the contract in question.

In so holding, the Court relied upon St Lawrence Cement, ${ }^{77}$ and distinguished the Divisional Court's own previous decision in Bot Construction Ltd $v$ Ontario (Minister of Transportation). ${ }^{78}$ There was "no broad public interest" in the award of a contract to run an agency liquor store such as was present in Bot Construction, a case involving the awarding of a road-widening contract. ${ }^{79}$ In Bot Construction, the Divisional Court had identified the following public interests in justification of its holding that the procurement process was amenable to judicial review: ${ }^{80}$

The tendering decision of the MTO has obvious broad public interest implications that extend beyond the interests of the contracting parties, not only with respect to the fairness and integrity of the process followed in the expenditure of significant public funds - totaling $\$ 2$ billion in 2008 and about $\$ 60$ million for this project. As noted in Shell [Canada Products Ltd v Vancouver] ${ }^{81}$ public concerns such as equality of access to government markets, integrity in the conduct of government business, and the promotion and maintenance of community values are relevant to government procurement powers. As well, the issues in the tendering process in this case have significant economic implications for both the steel industry in Canada and the road building industry in Ontario. The government is the only market for provincial road construction and it controls the pre-qualification of bidders and the economic opportunities for the road building industry.

When evaluated against those criteria, the contract in Lefroy Freshmart was "a purely commercial arrangement", ${ }^{82}$ not involving the expenditure of public funds, with no impact on third parties, and up for re-tendering every five years with no preference to the incumbent. ${ }^{83}$ As opposed

77 St Lawrence Cement v Ontario (Minister of Transportation), above n 59 and cited in 2169205 Ontario Inc (cob Lefroy Freshmart) v Ontario (Liquor Control Board) ibid.

78 Bot Construction Ltd v Ontario (Minister of Transportation) (2009) 99 OR (3d) 104 (Div Ct). In fact, on appeal, Bot Construction was reversed on the merits of the Divisional Court's holding that the Ministry's conduct of the procurement process was unreasonable: Bot Construction Ltd $v$ Ontario (Minister of Transportation) 2009 ONCA 879, 85 CLR (3d) 25. On the issue of the amenability of the procurement to judicial review, the Court stated at [19]: "We emphasise that we come to this conclusion without expressing any view as to the availability of judicial review with respect to the tendering process for government procurement contracts".

79 Ibid; cited in 2169205 Ontario Inc (cob Lefroy Freshmart) v Ontario (Liquor Control Board), above n 76, at [30].

80 Bot Construction Ltd v Ontario (Minister of Transportation), above n 78, at [24].

81 Shell Canada Products Ltd v Vancouver [1994] 1 SCR 231 at [11].

822169205 Ontario Inc (cob Lefroy Freshmart) v Ontario (Liquor Control Board), above n 73, at [31].

83 Ibid at [32]. 
to the situation in Bot Construction, the 2009 Procurement Directive of Management Board of Cabinet did not require the use of a competitive bidding process for the granting of a licence to run an agency liquor store.

While there is no room for quarreling with these factual differentiations between the two procurement processes, what is also obvious is that the two cases by no means establish a bright line distinction between contracts that are sufficiently imbued with broader public interest concerns as to attract the grounds and remedies of public law and those that do not and which are relegated to the non-reviewable category of a purely commercial contract.

The same is true of the judgment of the Federal Court of Appeal in Irving Shipbuilding Inc $v$ Canada (Attorney General), ${ }^{84}$ the judicial review equivalent of Design Services, ${ }^{85}$ in the sense that a subcontractor of an unsuccessful bidder (which was not suing) was seeking to have set aside on procedural unfairness grounds the award of a long-term contract to service Armed Forces submarines. There is nothing surprising in the judgment of Evans JA holding that, whatever the rights of the unsuccessful bidder, there was no basis for imposing an obligation on the Crown to afford procedural fairness in the course of the bidding process to potential subcontractors. However, characterising public contracts as resting "at the intersection of public law and private law", ${ }^{86}$ Evans JA in the list of considerations for denying process rights to the subcontractor did deploy at least one factor that would also have been relevant had the unsuccessful bidder been the applicant for review. After stating the public interest in the Crown "obtaining value for money by protecting the integrity of the procurement process" was not sufficient to justify extending procedural fairness rights to potential subcontractors, ${ }^{87}$ Evans JA went on to identify another public interest that pointed against the availability of judicial review in a procurement setting. Allowing judicial review in procurement settings would cause unnecessary delay in governments securing the goods and services needed for the effective discharge of their responsibilities; confining a disappointed bidder to an action for damages does not have that impact. ${ }^{88}$ Evans JA then proceeded to bolster this sense of an action for damages being the more appropriate remedy by reference to both Design Service and Dunsmuir.

84 Irving Shipbuilding Inc v Canada (Attorney General) 2009 FCA 116, (2009) 314 DLR (4th) 340.

85 Design Services Ltd v Canada, above n 35.

86 Irving Shipbuilding Inc v Canada (Attorney General), above n 84, at [1].

87 At [51].

88 At [54]. 
They exemplified the principle "that when the Crown enters into a contract, its rights and duties, and the available remedies, are generally to be determined by the law of contract". ${ }^{89}$

Nonetheless, Evans JA was not prepared to close off completely the possibility of awarding public law relief even to a subcontractor, "where the misconduct of public officials was so egregious that the public interest in maintaining the essential integrity of the procurement process was engaged". ${ }^{90}$

As examples, Evans JA instanced "fraud, bribery, corruption or other kinds of grave misconduct". ${ }^{91}$ This terminology is found in English and New Zealand case law, but difficult to reconcile with a unified or overarching conception of the principles of judicial review in which all exercises of public power are subject to either correctness or reasonableness review depending on a standard of review analysis.

Subsequently, in Air Canada v Toronto Port Authority, Stratas JA, also of the Federal Court of Appeal, set out a list of criteria that are relevant to the determination of whether a matter is sufficiently public in nature as to come within the judicial review authority of the Federal Court and Federal Court of Appeal. ${ }^{92}$ In terms of the language of the Federal Courts Act 1985, what was at stake was whether the activities of the Toronto Port Authority that were being called into question by the applicant for relief were being carried out by the Authority as a "federal board, commission or other tribunal."93 According to Stratas JA, only if they were would they be subject to an application for judicial review. ${ }^{94}$ While this was not a case involving procurement in any

89 At [60]. In this context, it is interesting to note the judgment of the Court of Appeal for Ontario in G-Civil Inc $v$ Canada (Minister of Public Works and Government Services), one of four cases reported as TeleZone Inc v Canada (Attorney General) (2008) 94 OR (3d) 19 (CA), in which the Court rejected the Crown's contention that it was a prerequisite to the bringing of an action for breach of contract in a federal procurement setting that the plaintiff first applied successfully for judicial review of the award of the contract. While the Attorney General of Canada elected not to seek leave to appeal this decision, the judgment was in effect approved by the Supreme Court by the general rejection of this species of argument in one of the other four cases: Canada (Attorney General) v TeleZone Inc v Canada 2010 SCC 62, [2010] 3 SCR 585.

90 At [61].

91 At [62].

92 Air Canada v Toronto Port Authority 2011 FCA 347. Unusually, the other two judges who sat on this case stated at [87]: "We have read the reasons now received from our colleague Stratas JA. We concur with his proposed disposition." Obviously, this calls into question the precedential value of the judgment.

93 Federal Courts Act RSC 1985 c F-7, ss 2(1), 18(1) and 18.1.

94 This is a limitation not directly expressed in the definition of "federal board, commission or other tribunal" in s 2(1) but operates by way of implication from that and the other relevant judicial review provisions of the Federal Courts Act. 
conventional sense (it was a case about landing rights at a federally controlled and operated airport), Stratas JA's general elaboration of the nature of the powers of public bodies and the eight criteria are clearly transferable to any discussion of the contractual powers of government in general and procurement in particular.

Before identifying the relevant criteria, Stratas JA stated: 95

Every significant federal tribunal has public powers of decision-making. But alongside these are express or implied powers to act in certain private ways, such as renting and managing premises, hiring support staff, and so on. In a technical sense, each of these powers finds its ultimate source in a federal statute. But, as the governing cases cited below demonstrate, many exercises of those powers cannot be reviewable. For example, suppose that a well-known federal tribunal terminates its contract with a company to supply janitorial services for its premises. In doing so, it is not exercising a power central to the administrative mandate given to it by Parliament. Rather, it is acting like any other business. The tribunal's power is best characterized as a private power, not a public power. Absent some exceptional circumstance, the janitorial company's recourse lies in an action for breach of contract, not judicial review of the tribunal's decision to terminate the contract.

He then moved to an identification of the criteria that may need to be addressed in making the public/private determination: ${ }^{96}$

- $\quad$ The character of the matter for which review is sought.

- $\quad$ The nature of the decision-maker and its responsibilities.

- The extent to which the decision is founded in and shaped by law as opposed to private discretion.

- $\quad$ The body's relationship to other statutory schemes and other parts of government.

- The extent to which a decision-maker is an agent of government or is directed, controlled or significantly influenced by a public entity.

- $\quad$ The suitability of public law remedies.

- $\quad$ The existence of compulsory power.

- An "exceptional" category of cases where the conduct has attained a serious public dimension.

95 Air Canada v Toronto Port Authority, above n 92, at [52].

96 At [60] 
This is a most useful list but one that in many instances will still require the courts to balance competing indicators arising out of a consideration of some or all of these factors. The bright line is still not there. However, as Stratas JA himself argues, any greater attempt at precision in resolution of the divide between public and private may not be feasible or even desirable given the range of activities that are potentially subject to this kind of inquiry and the range of judicial settings in which the question may arise. ${ }^{97}$

\section{B New Zealand}

\section{Threshold}

In some respects, the law of New Zealand on judicial review of the exercise of contractual powers in general and procurement in particular may be more clear-cut than it is in Canada. In part, this is the result of 1977 amendments to the Judicature Amendment Act 1972, and defining "statutory power", a threshold to the application of the Act's judicial review provisions, as "a power or right conferred by or under any Act, or by or under the constitution or other instrument of incorporation, rules or bylaws of any body corporate". ${ }^{98}$

While that definition does not reach the exercise of powers by companies incorporated under the general corporations legislation, it has certainly expanded the scope of judicial review of the Act to bodies that in other jurisdictions would be categorised as private in nature. ${ }^{99}$ Also, Taylor notes that even bodies not coming within the scope of s 3(1) of the Judicature Amendment Act may be subject to judicial review under residual common law powers, and provided for procedurally in pt 30 of the High Court Rules 2008.

As a consequence, most of the New Zealand litigation in the domain of judicial review of contracting and procurement decisions tends to be concerned with the grounds and intensity of review rather than its availability, at least as a threshold matter. However, there are still some lingering questions about the reach of review under the Judicature Amendment Act and residual common law by way of pt 30 of the High Court Rules. These doubts emerge from the judgments of

97 At [58].

98 Judicature Amendment Act 1977, s 10(1) amending the Judicature Amendment Act 1972, s 3(1) (emphasis added).

99 For a more detailed discussion see Graham Taylor (ed) Judicial Review: A New Zealand Perspective, above n 11 , chs 1 and 2 . 
the New Zealand Court of Appeal in both Royal Australasian College of Surgeons v Phipps, ${ }^{100}$ and Lab Tests Auckland Ltd v Auckland District Health Board. ${ }^{101}$

In the former, as well as confirming that review under the Judicature Amendment Act did not reach the commercial operations of all bodies corporate, ${ }^{102}$ the Court made it quite clear that there was almost certainly a gloss, in the form of a restriction on the reach of the term "statutory power" in s 3(1), of the kind that Stratas JA in Air Canada recognised in relation to the threshold provisions of the Federal Courts Act: ${ }^{103}$

We are not concerned with a body making a series of commercial judgments nor ... with someone making a decision on all manner of questions of public interest in a broad policy context.

The first of these certainly suggests that not all contractual activity crosses the judicial review threshold, even for bodies that otherwise or in other respects are subject to review under the Judicature Amendment Act. The second qualification is rather more difficult to parse but may well represent a justiciability threshold that eliminates judicial review even for clearly statutory or governmental bodies.

In Lab Tests, Arnold and Ellen France JJ in their joint judgment accepted that the Auckland District Health Board was subject to judicial review with respect to an RFP for the provision of pathology services. Rather, their major preoccupation was with the scope of the grounds of review in the context of that procurement exercise. In contrast, Hammond J noted that the parties to the litigation had accepted the availability of judicial review in the threshold sense. ${ }^{104}$ However, on the basis of a discussion of the law and literature on the public/private divide, he stated: ${ }^{105}$

My concern is that I would not want it to be thought in other cases that, on the basis of what has happened in the case in front of us at this time, counsel can automatically assume reviewability in this subject area.

100 Royal Australasian College of Surgeons v Phipps [1999] 3 NZLR 1 (CA).

101 Lab Tests Auckland Ltd v Auckland District Health Board, above n 7. Hanna Wilberg in "Administrative Law" [2010] NZ Law Review 177, at 180-183, canvasses this case extensively. She also identifies other authorities suggesting limits on the literal meaning of "statutory power" in the Judicature Amendment Act at $178-181$.

102 Royal Australasian College of Surgeons v Phipps, above n 100, at 12.

103 Ibid.

104 Lab Tests Auckland Ltd v Auckland District Health Board, above n 7, at [361].

105 At [360]. 
He then concluded his judgment with the following, possibly for him, rhetorical question: "should the courts allow what may be thought to be more like private law issues to be litigated in public law drag?" 106

That this argument has some pull and that there may be room for further refinement of the threshold to judicial review under the Judicature Amendment Act may be seen in the decision of the Supreme Court of New Zealand denying leave to appeal in this case: ${ }^{107}$

The Court of Appeal discussed the High Court Judge's approach to the questions of whether the decision of the Boards to enter into the contract was reviewable and as to the scope of any such review. In the reasons of the Appeal Court Judges, different possible approaches are identified. If the choice of the correct approach had been determinative, this may well have been a case for leave. The facts, as found by the Court of Appeal were, however, such that the outcome would be the same whatever approach is adopted

In the concluding comments to their joint judgment, Arnold and Ellen France JJ expressed another concern about the appropriateness of judicial review for the kind of case that confronted the Court of Appeal in Lab Tests: ${ }^{108}$

This is a lengthy judgment, much longer than is desirable. But to deal with the submissions advanced, we have had to examine the evidence in some detail. This process has highlighted that disputes such as this are not well-suited to being dealt with in judicial review proceedings, at least where there are broadly framed allegations of the type made in this case. The factual and other subtleties are too great to be dealt with in what is supposed to be "a relatively simple, untechnical and prompt procedure" ...

which normally does not involve cross-examination.

This certainly suggests the possibility of denial of judicial review (most likely also as a threshold matter) on the basis of the existence of a more convenient alternative remedy, this time, a civil action in contract. To do that, of course, would then raise the Pratt Contractors question all over again: Should public law grounds of judicial review be available in the context of an action in contract (or some other civil proceeding) involving actions or decision-making otherwise amenable to judicial review under either the Judicature Amendment Act or pt 30 of the High Court Rules?

\section{Grounds}

Mercury Energy Ltd $v$ Electricity Corporation of New Zealand Ltd remains the leading authority on the scope of judicial review of government contracting decisions including procurement. ${ }^{109}$ It

106 At [405].

107 At [4] (emphasis added).

108 At [342] (citations omitted). 
concerned a State Owned Enterprise's termination of a contract for the supply of bulk electricity. Notwithstanding the fact that State Owned Enterprises were registered under the Companies Act 1955, the Judicial Committee of the Privy Council held there was a sufficient statutory and public flavour to bring their activities within the reach of the Judicature Amendment Act 1972. However, thereafter, the Judicial Committee indicated that the scope for review at least on substantive grounds was exceptional. It started with the non-controversial statement that it was only if the decision was contrary to law that the Court could intervene. ${ }^{110}$ It was, however, in response to the arguments that, in this instance, the State Owned Enterprise had acted contrary to law by taking a decision that could not withstand scrutiny under Wednesbury unreasonableness principles, ${ }^{111}$ that the narrowness of the Privy Council's conception of the scope for intervention became apparent. ${ }^{112}$ In essence, the Privy Council conceded to the Electricity Corporation virtually unlimited discretion in its business judgments as to what would be appropriate to carry out its statutory mandate. ${ }^{113}$ That then led to the oft-quoted statement, picked up by Evans JA in a Canadian procurement setting in Irving Shipbuilding: ${ }^{114}$

It does not seem likely that a decision by a state enterprise to enter into or determine a commercial contract to supply goods and services will ever be the subject of judicial review in the absence of fraud, corruption or bad faith.

Of course, even in the domain of the substantive review of contracting powers, context is important and, under certain configurations, may dictate more intrusive review. In particular, as the majority of the Court of Appeal made clear in Lab Tests, context may also dictate otherwise. In particular, to take the authority of the courts further would require something like the statutory imposition of substantive limitations or obligations with respect to the contractual processes or their outcome. ${ }^{115}$ What is clear however from both the majority and concurring judgments in Lab Tests is that the Court of Appeal was counseling lower courts to exercise extreme caution in implying substantive obligations in this kind of setting particularly on the basis of a conception of the court's

109 Mercury Energy Ltd v Electricity Corporation of New Zealand Ltd [1994] 2 NZLR 385 (PC), discussed by Graham Taylor (ed) Judicial Review: A New Zealand Perspective, above n 11, at [2.04].

110 Mercury Energy Ltd v Electricity Corporation of New Zealand Ltd, ibid at 528.

111 Associated Provincial Picture Houses Ltd v Wednesbury Corp [1948] 1 KB 223 (CA).

112 On this, see the critical case comment by Michael Taggart "Corporatisation, Contracting and the Courts" [1994] PL 351.

113 Mercury Energy Ltd v Electricity Corporation of New Zealand Ltd, above n 109, at 390.

114 Ibid at 391; see also Irving Shipbuilding Inc v Canada (Attorney General), above n 84

115 Lab Tests Auckland Ltd v Auckland District Health Board, above n 7, at [45]. 
role as the guardian of integrity, probity and good administration in the exercise of such powers. ${ }^{116}$ In other words, the judgment leaves no room for the imposition of an at-large unreasonableness or even Wednesbury unreasonableness standard of review, though Hammond $\mathrm{J}$ appears to want to leave open the possibility of some sort of substantive unfairness principle to counter an exercise of power that "is so grossly unfair that it ought to be impugned". ${ }^{117}$

In the domain of process or fair procedures, the message is similar. Absent specific or very clear indicators in the relevant statute (such as consultation requirements) or possibly legitimate expectations arising out of specific assurances or relied on patterns of conduct, courts should not impose typical common law procedural fairness obligations in the context of judicial review of contracting, in general, and procurement in particular. This also meant that there was no room for the application of the reasonable apprehension of bias that generally applied to adjudicative bodies, and that the content of what was impermissible and reviewable conflict of interest and the use of confidential information (the principal bases of challenge in Lab Tests itself) should be carefully calibrated to "the nature of the body making the decision and the statutory setting within which the decision is made". ${ }^{118}$

Nonetheless, the majority was prepared to expand on the grounds identified in Mercury Energy to include situations analogous to "fraud, corruption or bad faith." Moreover, as examples in the domain of process, the Court gave situations: ${ }^{119}$

... where an insider with significant inside information and a conflict of interest has used that information to further his or her interests and to disadvantage his or her rivals in a tender. In such a case,

it may be that the integrity of the contracting process has been undermined in the same way as in the case of corruption, fraud and bad faith.

It is, however, significant that the Court of Appeal, relying in large measure on statutory context and a degree of tolerance for what in other settings might well have been regarded as a conflict of interest or improper use of confidential information, allowed the appeal from the judgment below in which the process had been found wanting on these very grounds. What may have at the end of the day been critical in all of this is that the first instance judge based these conclusions on a probity in

116 At [60], [85] and [343]-[344] per Arnold and Ellen France JJ, and [367]-[369], and [401]-[403] per Hammond J.

117 At [392].

118 At [57].

119 At [91]. Hammond $\mathrm{J}$ appears much more skeptical about the place of judicial review for conflict of interest and improper use of confidential information at least in settings such as exemplified by government contracting (including procurement) regimes: ibid at [400]-[403]. 
public decision-making' approach. ${ }^{120}$ In short, as in the instance of substantive review of contracting decisions, it is going to take a very clear case for a procedural unfairness or process argument to prevail in this domain.

\section{WHAT TO MAKE OF ALL OF THIS?}

The regulation of government contracting in general and procurement in particular is a complex task and the reality is that judicial review and private law actions based largely on common law precepts and principles cannot serve as anything other than a random regulator. It is also the case that there are strong practical reasons why affected parties and disappointed bidders in particular will not have recourse to the courts in such matters. Aside from the expense and potential for complexity in such litigation as well as the spectre of a 'deep pocket' defendant or respondent, as exemplified by Lab Tests, there are often strategic reasons for not litigating perceived grievances with procurement and contracting processes generally. Rightly or wrongly, litigating such cases against governments and public bodies might be seen as adversely affecting the prospects of future lucrative contracts with the same defendant or respondent. In the case of judicial review of procurement and other forms of contract awarding, even if the case is made out, it is unlikely to produce what the applicant really wants: the contract. By the time the case reaches the court on judicial review, it may simply be too late to undo an award of a contract and a mere declaration will be the only vindication, and, of course, if success on such an application is based on process grounds, as is more likely, the best that can be hoped for is a remission back to the authority for the process to be conducted all over again with no guarantee of success for the litigating party.

In some cases such as Mercury Energy, ${ }^{121}$ and the judgment of Hammond $\mathrm{J}$ in Lab Tests, ${ }^{122}$ store is placed in political accountability as the appropriate way in which to deal with the malfunctioning both procedurally and substantively of government and public agency contracting. However, except in the most egregious cases involving the most significant of government or public body contracts, conventional political accountability is not likely to be a very effective regulator either. Indeed, it is somewhat ironic that the scope and intensity of judicial scrutiny of government contracting is currently at its apex in situations where there are broader public interests at stake (as evidenced by the judgment of the Ontario Divisional Court in Bot Construction), when it is these kinds of contract that are more likely to produce accountability in the political arena.

Potentially far more effective as accountability mechanisms are internal government regimes charged with developing and policing legislatively or administratively developed principles and

120 At [26], as described by Arnold and Ellen France JJ.

121 Mercury Energy Ltd v Electricity Corporation of New Zealand Ltd, above n 109, at 391.

122 Lab Tests Auckland Ltd v Auckland District Health Board, above n 7, at [403]. 
rules respecting government contracting, and especially procurement. Indeed, to the extent that such regimes or specific calls for bids are either automatically subject to the scrutiny of a fairness commissioner or some like official or contain a readily accessible appeal mechanism, the chances of a process that works fairly and efficiently and in the interests of the public authority, bidders and the public interest increases exponentially. In this regard, a good example is provided by the complaints jurisdiction of the Canadian International Trade Tribunal established by the Canadian International Trade Tribunal Act 1985, ${ }^{123}$ and the Canadian International Trade Tribunal Inquiry Regulations. ${ }^{124}$ It provides a model worthy of consideration. ${ }^{125}$

Nonetheless, in both New Zealand and Canada, litigation in either the public or private law mode remains a reality, albeit a relatively infrequent one as emphasised by Hammond $\mathrm{J}$ in Lab Tests. ${ }^{126}$ As already noted, it is also a frequent source of complaint that that the jurisprudence in this area is inconclusive and often conflicting (even within the same jurisdiction) as to the appropriate principles. This makes litigation even more of a gamble than in other domains and that is regrettable for both private sector litigants, public bodies, and, more generally, the public interest.

Let me, however, make some modest suggestions for resolving some of the problems emerging from the New Zealand and Canadian jurisprudence described in this paper. First, in so far as there are lingering doubts about the ability of litigants to rely on public law principles and rules when they elect to proceed by way of civil action, there seems no principled basis for denying litigants this capacity. Provided the matter is one which would, in a judicial review setting, attract the application of public law principles and rules, litigants should also be able to rely on those same public law principles and rules as the basis for or as part of the grounds of their civil action. As exemplified by cases as early as Cooper v Board of Works for Wandsworth District in 1863, ${ }^{127}$ the invocation of public law concepts has been acceptable in the setting of a civil suit. It is also worth recollecting that, albeit that it has now been discredited on other grounds, Knight $v$ Indian Head School Division No 19 was an action for breach of contract. ${ }^{128}$

123 Canadian International Trade Tribunal Act RSC 1985 (4th Supp) c 47.

124 Canadian International Trade Tribunal Inquiry Regulations SOR/93-602.

125 Though it should be noted that the decisions of this Tribunal are judicially reviewable by the Federal Court of Appeal under the Federal Courts Act: for example, see Cougar Aviation Ltd v Canada (Minister of Public Works and Government Services) (2000) 26 Admin LR (3d) 30 (FCA); Almon Equipment Ltd v Canada (Attorney General) (2010) 12 Admin LR (5th) 161 (FCA); and Northrop Grumman Overseas Services Corporation v Canada (Attorney General) 2009 SCC 50, [2009] 3 SCR 309.

126 Lab Tests Auckland Ltd v Auckland District Health Board, above n 7, at [396]-[397].

127 Cooper v Board of Works for Wandsworth District (1863) 143 ER 414 (CP).

128 Knight $v$ Indian Head School Division No 19, above n 62. 
Related to this point, the courts in both countries should also accept that in many instances a civil action should be the preferred remedial choice even in situations where the litigant is challenging public contracting (including procurement) on public law grounds. There should generally be no quarrel with judges who exercise the discretion to deny public law relief on the ground that a civil action is a more appropriate remedy for any of the following reasons: the inappropriateness in the particular circumstances of public law remedies and especially a setting aside and the greater appropriateness of monetary relief (most commonly damages); the greater capacities of civil actions (as opposed to most forms of public law judicial review processes) to handle complex questions arising out of public contracts (and, in particular, where there are seriously contested facts); and the potential for the relevance of both private and public law principles in the particular litigation and the desirability of having all issues resolved in the one venue.

In terms of the threshold for applications for judicial review, the courts should continue to be generous or liberal in making decisions on whether the threshold has been crossed leaving the difficult issues to be handled by reference to the availability of particular grounds of review and a consideration of the intensity with which review or scrutiny should be conducted. However, in principle, there should be no objection to courts imposing a gloss on the wording of the threshold provisions of judicial review statutes to exclude in limited cases those exercises of contractual and procurement power that are clearly (generally by virtue of clear legislative specification) subject only to private law principles and rules.

In the domain of procedural challenges to contractual (including procurement) decisions, I can see nothing wrong with the current approach, which treats procedural claims in such cases as operating at the low or less formal end of a sliding scale of hearing obligations. This is the stuff of conventional judicial review law involving procedural challenges (including bias and conflict of interest). The level of entitlement at common law is very context sensitive and there is no reason for abandoning that approach in the instance of contracting generally and procurement in particular.

Similarly and despite the fact that this is the basis of much criticism on the grounds of indeterminacy, I see no reason to deny the courts the capacity to calibrate the scope of substantive review not just by reference to the general characteristics of public contracting and procurement but to the specific contractual or procurement regime that is before the court. In doing so, the court should be paying attention as some judges have urged to a range of factors or considerations, most common among which are the particular nature of the decision-maker, the kind of decision that is before the court, and the particular details of the regime under which the contract is being formed or performed. In this context, it may be incumbent on the Canadian courts to recognise that their 'two sizes (correctness or reasonableness) fits all' brand of judicial review is simply not apposite to 
accommodate the world of public contracting and procurement; that there may have to be some recognition of the importance of conducting review in this domain by reference to discrete grounds of judicial review. ${ }^{129}$

This, of course, leaves much still to be resolved and, in particular, a more developed sense, beyond the Mercury Energy categories of the substantive grounds of review, of the badges of what constitute unfair treatment and failing to treat those seeking to enter contracts with the government equally in the context of procurement and other public and contractual decision-making.

However, almost certainly the most important issue is that of articulating the values that reviewing courts should bring to the table when scrutinising public body contracting decisions and behaviour or, putting it another way, whether reviewing courts, either in judicial review or civil action mode, have any role to play in imposing broader public interest obligations on public bodies as contractors than they would on a purely private relationship, contractual or otherwise. This issue was joined in Lab Tests and largely resolved by all three judges against what counsel for the applicant/respondent urged on them: to approach the task of review from the perspective of a principle of "good hygiene in public decision-making". 130

As the discussion reveals, this is an issue that raises profound issues about the role of both courts and government. However, I would venture to say that there are principles of probity and integrity in the functioning of public authorities that should be legitimately available to reviewing courts without giving rise to the criticism that they are venturing into areas beyond their ken and inappropriately engaging in the substantive review of decisions best left to the public body subject to political checks. After all, if in a procurement setting, the objective is the integrity of the bidding system, there seems clear room in that context for taking into account at least some of the many public interest considerations identified by the Ontario Divisional Court in Bot Construction and that bear on the particular role and responsibilities of public bodies.

129 In Lab Tests Auckland Ltd v Auckland District Health Board, above n 7, at [374]-[378], Hammond J makes this point using, among others, the example of Canada.

130 Ibid at [343]. 